\title{
Comparison between Two Selected Saccharomyces cerevisiae Strains as Fermentation Starters in the Production of Traditional Cachaça
}

\author{
Fátima de Cássia Oliveira Gomes ${ }^{1,2}$, Roberta Amália de Carvalho Araújo ${ }^{1}$, Patrícia Silva \\ Cisalpino $^{1}$, Elizabeth Spangler Andrade Moreira ${ }^{1}$, Carlos Leomar Zani ${ }^{3}$ and Carlos \\ Augusto Rosa ${ }^{1 *}$ \\ ${ }^{1}$ Departamento de Microbiologia; Instituto de Ciências Biológicas; Universidade Federal de Minas Gerais; Belo \\ Horizonte - MG - Brasil. ${ }^{2}$ Departamento de Química; Centro Federal de Educação Tecnológica; Belo Horizonte - \\ MG - Brasil. ${ }^{3}$ Laboratório de Química de Produtos Naturais, Centro de Pesquisa Renê Rachou; Av. Augusto de \\ Lima, 1715; Belo Horizonte - MG - Brasil
}

\begin{abstract}
Two Saccharomyces cerevisiae strains were tested as the starter yeasts in a traditional cachaça distillery. The strains used were S. cerevisiae UFMG-A829, isolated from a cachaça fermentation process, and S. cerevisiae K1V1116, obtained from the wine industry. The permanence of each strain in the fermentation must was determined by RAPD (Random Amplified Polymorphic DNA)-PCR, with primer M13. Both yeast strains were prevalent in the vats for approximately 30 days. Indigenous non-Saccharomyces and indigenous S. cerevisiae strains were isolated in lower counts during the fermentation period. Indigenous S. cerevisiae strains were molecularly distinct when compared to the starter yeasts. The two yeasts appeared promising starter yeasts in the fermentation process to produce traditional cachaça.
\end{abstract}

Key words: cachaça, Saccharomyces cerevisiae, starter strains, fermentation

\section{INTRODUCTION}

Indigenous or traditional fermented foods are those popular products that can be prepared in the household or in cottage industries using relatively simple techniques and equipment (Aidoo et al. 2006). Some of these products have undergone industrial development and are also now manufactured on a large scale (Wood, 1998; Hui et al., 2004). Cachaça produced in the state of Minas
Gerais can be considered a traditional beverage, since it is prepared according to the definition as above. The state of Minas Gerais is the largest producer of traditional cachaça in Brazil. The number of cachaça producing plants is estimated to be around 8,000, accounting for approximately 230 million liters per year. Traditional cachaça is a product of the distillation of sugarcane must in copper alembics. The fermentation process is spontaneous, and involves exclusively the

\footnotetext{
* Author for correspondence: carlrosa@icb.ufmg.br
} 
indigenous microbiota present in the must and equipments (Morais et al., 1997). Fermentation cycles last an average of $24 \mathrm{~h}$ and natural yeast preparations (named "fermento caipira") are used throughout the production season (May to December). During the fermentation cycle, it is possible to isolate different yeast species in the vats. Nevertheless, Saccharomyces cerevisiae is the prevailing species (Morais et al., 1997; Pataro et al., 1998, 2000; Guerra et al., 2001). Pataro et al. (2000) and Guerra et al. (2001) have detected different $S$. cerevisiae strains in the fermentation vats during the season, and this strain diversity may cause the sensory properties of cachaça to vary during the production.

$S$. cerevisiae strains have been used as fermentation starters for the majority of fermented and distilled beverages (Kunkee and Bisson, 1993; Cedeño, 1995; Gutiérrez et al., 1997; Fahrasmane and Parfait, 1998; Romano et al., 2003; Victoria Lopez et al., 2003; Valero et al., 2005; Melo et al., 2007). Among the advantages of using selected strains are faster fermentation start-up, lower adverse contamination risks and preservation of the sensory characteristics of the beverage from season to season. Dorneles et al. (2005) studied the influence of using selected $S$. cerevisiae in the elaboration of Terci red wine from Colombo, Parana, Brazil. The authors showed that the use of selected yeasts contributed to the improvement of the physical-chemical parameters and wine quality obtained, reducing undesirable components in the finished product, like the volatile acidity and methanol, when compared to the artisanal wine.

Oliveira et al. (2004) defined some fermentation characteristics in the selection of starter yeasts to use in the production of cachaça. The fermentation yield, ethanol content in the wine and the maximum specific rate for cell growth were identified as important parameters in the selection of strains. The physiological characteristics of the selected $S$. cerevisiae strains, such as the ability to grow at high temperatures and at high alcohol concentrations, osmotolerance, high levels of invertase activity and trehalose accumulation, and production of low levels of volatile acidity are also desirable characteristics that allow these strains to dominate the cachaça fermentation process (Pataro et al. 2002). This study aimed to compare the use of one indigenous and one commercial $S$. cerevisiae strain as starters to the fermentation process of traditional cachaça production, with observation of the permanence times of the starter yeasts.

\section{MATERIALS AND METHODS}

\section{Strain origin and physiologic tests}

Two $S$. cerevisiae strains were used in the experiments. Strain UFMG-A829 was obtained from the yeast collection of the Laboratory of Yeast Ecology and Biotechnology, Department of Microbiology, Federal University of Minas Gerais. The strain was isolated from spontaneous fermentation during the cachaça production process (Pataro et al. 2000). This strain was compared to a commercial strain of $S$. cerevisiae K1-V1116 (Lallemand - Canada) that is one of the most widely active dry wine yeasts in the world. This strain is a rapid starter with constant and complete fermentation at 10 and $35{ }^{\circ} \mathrm{C}$, and it is capable of surviving difficult conditions such as low nutrient musts and high levels of sulfur dioxide $\left(\mathrm{SO}_{2}\right)$ and sugar (http://www.lalvinyeast.com/strains.asp). Methods for the physiological tests of osmotolerance, maximum growth and fermentation temperature, resistance to ethanol, invertase activity, and accumulation of trehalose have been presented in detail by Pataro et al. (1998) and Gomes et al. (2002).

\section{Large-scale fermentations}

Fermentations were carried out in a distillery in the city of Esmeraldas, state of Minas Gerais. For the preparation of the starter strains, strain UFMGA829 was grown in modified Sabouraud agar (glucose $2 \%$, peptone $1 \%$, yeast extract $0.5 \%$, and agar $2 \%$ ) at room temperature for $24 \mathrm{~h}$. One milliliter of a suspension containing $1 \times 10^{7}$ cells was inoculated in flasks containing $100 \mathrm{ml}$ SCY broth (sugarcane juice $50 \%$, glucose $0.5 \%$, yeast extract $0.5 \%$, and distilled water $50 \%$ ). The flasks were incubated in a rotatory shaker (New Brunswick Scientific) at $150 \mathrm{rpm}, 25 \pm 1^{\circ} \mathrm{C}$ for 24 h. After this period, the pre-inoculum was transferred to flasks containing $5 \mathrm{~L} \mathrm{SCY}$ broth, and incubated at room temperature $\left(25 \pm 3^{\circ} \mathrm{C}\right)$ for $24 \mathrm{~h}$. Ten liters of this second pre-inoculum was added to the vats. The fermentations were conducted in 1,500-L stainless steel vats. The pre- 
inoculum was mixed with $90 \mathrm{~L}$ sugarcane juice at $8^{\circ}$ Brix. After $24 \mathrm{~h}$, a $200-\mathrm{L}$ volume of sugarcane juice $\left(10^{\circ}\right.$ Brix) was added to the fermentation vat. On the third day, a $300-\mathrm{L}$ volume of sugarcane juice $\left(12^{\circ}\right.$ Brix $)$ was added. On the fourth day, one $400-\mathrm{L}$ volume sugarcane juice $\left(20^{\circ} \mathrm{Brix}\right)$ was then added to the vat containing the selected yeast, thus completing a 1,000-L final fermentation volume. After $24 \mathrm{~h}$, the wine produced was distilled, and a new fermentation cycle started. For strain K1V1116, $500 \mathrm{~g}$ of the dry yeast were inoculated directly into the fermentation vat containing $500 \mathrm{~L}$ sugarcane juice diluted to $8^{\circ}$ Brix. On the second day, the volume inside the vat was completed to $1,000 \mathrm{~L}$, and on the third day the wine was distilled. Fermentation was terminated when the Brix scale reading for the wine was zero. The wine was subsequently distilled in a copper still (alembic). This distillery did not resort to centrifugation to carry out cell recycling, and the yeasts, on average, took $4 \mathrm{~h}$ to decant spontaneously, with the starter strain corresponding to $25 \%$ of the vat's volume. Samples of the sugarcane must were collected on days $3,5,11,18,25$ and 34 after the first distillation to produce cachaça during the two experiments which were carried out. The duration of the experiments was determined with the daily observation of cachaça volatile acidity levels and fermentation times. During the experiments, vat contents were discarded when the volatile acidity of the cachaça, expressed as acetic acid, reached values over $150 \mathrm{mg} \mathrm{ml}^{-1}$ anhydrous alcohol, the maximum limits established by Brazilian law (Brazil, 2005), or when the fermentation cycle, normally between 18 and $24 \mathrm{~h}$, lasted over $30 \mathrm{~h}$.

\section{Yeast counts and identification}

For the determination of yeast populations, $0.1 \mathrm{~mL}$ aliquots of appropriate decimal dilutions were spread on SCY (sugarcane juice $50 \%$, glucose $0.5 \%$, yeast extract $0.5 \%$, distilled water $50 \%$, and agar 2\%), and lysine agar [Yeast carbon base (Difco) $1.17 \%$, lysine $0.056 \%$, agar $2 \%$, and chloramphenicol $0.01 \%$ ] for non-Saccharomyces species. Plates were incubated at $25^{\circ} \mathrm{C}$ for 5 days. After growth, ten yeast colonies from each fermentation vat were selected, at the highest dilution plate of SCY agar, all of which represented the same morphotype. Also, at least one sample of each distinct colony morphotype was collected for physiological and molecular characterization. Each different yeast morphotype from lysine agar was counted and purified for identification. The yeast isolates were maintained in YM (yeast extract $0.5 \%$, malt extract $0.5 \%$, glucose $1 \%$, peptone $0.5 \%$, and agar $2 \%$ ) slants or liquid nitrogen. The yeasts were identified by methods proposed by Yarrow (1998) using the taxonomic keys presented by Kurtzman and Fell (1998).

\section{DNA extraction and RAPD assay}

Yeast DNA was extracted as described by Pataro et al. (2000). For the PCR assays, the primer M13 (5'-GAGGGTGGCGGTTCT-3') was used (Torriani et al., 1999; Guerra et al., 2001). The PCR assay was conducted as described by Guerra et al. (2001). PCR products were analyzed on $1 \%$ agarose gel electrophoresis (1X Tris-acetate TAE buffer), stained with ethidium bromide and visualized under UV light and photographed.

\section{RESULTS AND DISCUSSION}

The two starter strains tested were able to grow at temperatures of up to $41^{\circ} \mathrm{C}$, to ferment glucose at $46^{\circ} \mathrm{C}$, and to grow in the $10 \%$ ethanol medium. Apart from this, the strains were also able to grow in a medium containing $50 \%$ glucose and $8 \%$ ethanol. The results showed that the strains studied were adapted to the conditions observed in the fermentation vats. The average temperature of the cachaça fermentations, as practiced in the state of Minas Gerais, is around $30^{\circ} \mathrm{C}$ and may go up to $40^{\circ} \mathrm{C}$ in the hotter regions of the state (Pataro et al. 2002). The data obtained for tolerance to high glucose and ethanol concentrations, as well as the ability to grow and to ferment at high temperatures, were similar to the results obtained by Pataro et al. $(1998,2002)$ for yeast isolated during the cachaça fermentation processes.

Strain UFMG-A829 exhibited $110 \mu \mathrm{mol}$ of reducing sugars per $\mathrm{mg} / \mathrm{cells}$.min of invertase activity, and strain K1-V1116 produced $40 \mu \mathrm{mol}$ of reducing sugars per $\mathrm{mg} /$ cells.min. Studies carried out by Pataro et al. $(1998,2002)$ have shown an elevated invertase activity in $S$. cerevisiae strains isolated from the traditional fermentation processes to produce cachaça. The values observed for these strains reached $100 \mu \mathrm{mol}$ reducing sugars/mg cells.min. The daily addition, to the fermentation vats, of sugar cane juice with approximately $16 \%$ sugar made this environment selective for yeast strains that exhibited a high 
invertase activity.

The intracellular trehalose level did not vary considerably between the two strains. Strain UFMG-A829 accumulated $28.4 \mu \mathrm{mol}$ glucose wet weight, and strain K1-V1116 built up more than $40 \mu \mathrm{mol}$ glucose/g wet weight. The strains that produce high trehalose levels may prevail for longer within the fermentation process, as they pose a better resistance against the stress conditions inherent to the process (Pataro et al., 2002). The trehalose accumulation capacity may be involved in the survival of $S$. cerevisiae strains in cachaça fermentation environments.

S. cerevisiae UFMG-A829 prevailed throughout the fermentation process for 34 days during the two experiments carried out (Table 1). After this time, the volatile acidity values of the produced cachaça were above the maximum limits established by Brazilian law (Brazil, 2005), and the vat contents were discarded. The non-
Saccharomyces isolates in vats inoculated with strain UFMG-A829 were identified as belonging to the genera Candida, Schizosaccharomyces and Pichia. S. cerevisiae K1-V1116 prevailed in the process during the 28 days in the first experiment and 34 days in the second. In the vats inoculated with this strain, the non-Saccharomyces yeasts isolated belonged to species of the genera Candida, Kloeckera, Rhodotorula and Torulaspora. The variations in the numbers of $S$. cerevisiae populations may be explained by the circumstance of sample collection, with higher counts observed during tumultuous fermentation and lower counts seen at the end of the fermentative cycle. Both starter strains presented similar yields of cachaça (about 1701 for each 1,000 1 of distilled wine) during the time that these strains were prevalent in the fermentation vats in both experiments (data not shown).

Table 1 - Numbers (cfu.ml ${ }^{-1}$ ) of yeast species recovered at different times from vats inoculated with two Saccharomyces cerevisiae starter strains in a cachaça distillery.

\begin{tabular}{|c|c|c|c|c|c|c|c|}
\hline \multirow[t]{3}{*}{+2} & \multirow[t]{2}{*}{ Yeasts } & \multicolumn{6}{|c|}{ Times $^{1}$} \\
\hline & & I & II & III & IV & $\mathbf{V}$ & VI \\
\hline & S. cerevisiae UFMG-A 829 & & & & & & \\
\hline \multirow[t]{6}{*}{$\mathrm{A}^{2}$} & Candida apis & - & - & 1 & - & - & - \\
\hline & C. famata & - & - & 2 & - & - & - \\
\hline & C. gropengiesseri-like ${ }^{4}$ & 1 & - & - & - & - & - \\
\hline & S. cerevisiae indigenous & 3 & - & - & - & - & - \\
\hline & Pichia membranifaciens & 2 & - & - & - & - & - \\
\hline & S. cerevisiae UFMG-A 829 & $>300$ & 86 & 19.1 & 26 & 9.43 & 0.36 \\
\hline \multirow[t]{5}{*}{$\mathrm{B}^{3}$} & C. parapsilosis & - & 1 & - & - & - & - \\
\hline & S. cerevisiae indigenous & - & 1 & 1 & - & - & 1 \\
\hline & Schizosaccharomyces pombe & - & 1 & - & - & - & - \\
\hline & S. cerevisiae UFMG-A 829 & $>300$ & 8 & 3 & 24.3 & 146 & $<1 \times 10^{4}$ \\
\hline & S. cerevisiae K1-V1116 & & & & & & \\
\hline \multirow[t]{7}{*}{$\mathrm{A}^{2}$} & C. famata & - & 2 & 8 & - & - & \\
\hline & C. gropengiesseri-like ${ }^{4}$ & 1 & - & - & - & - & \\
\hline & Kloeckera apis & 40 & - & - & - & - & \\
\hline & Rhodotorula mucilaginosa & - & 1 & - & - & - & \\
\hline & S. cerevisiae indigenous & 5 & - & - & - & - & \\
\hline & Torulaspora delbrueckii & - & - & 2 & - & - & \\
\hline & S. cerevisiae K1-V1116 & $>300$ & $>300$ & 1400 & 8.76 & 1.03 & \\
\hline \multirow[t]{3}{*}{$\mathrm{B}^{3}$} & C. famata & - & 1 & - & - & - & - \\
\hline & S. cerevisiae indigenous & - & - & 3 & - & - & 1 \\
\hline & S. cerevisiae K1-V1116 & 4.3 & 10.7 & 56 & 14 & 0.43 & 0.04 \\
\hline
\end{tabular}

Values expressed as $10^{6} \mathrm{cfu}^{\mathrm{m}} \mathrm{m}^{-1}$.

${ }^{1}$ Times I, II, III, IV, V and VI after the start of fermentation were at 3, 5, 11, 18, 28 and 34 days, respectively.

${ }^{2} \mathrm{~A}=$ first experiment (July of 2000).

${ }^{3} \mathrm{~B}=$ second experiment (August of 2001); ${ }^{4}$ Similar to C. gropengiesseri. 
The molecular profiles of the $10 \mathrm{~S}$. cerevisiae isolates obtained by RAPD-PCR analysis at each collection were identical to the respective starter strains used (Fig. 1). Indigenous $S$. cerevisiae isolates with rough colonial texture and irregular margins were obtained from the vats with population counts higher than the selected start strains at the end of the second experiment. The RAPD-PCR profiles of five of these isolates from vats inoculated with strain UFMG-A829 are shown in Figure 2. Three of these isolates presented molecular profiles identical to this starter strain, and two of them presented molecular profiles which were identical to each other, while being different from the selected starter strain. These latter isolates were considered to be indigenous $S$. cerevisiae of the fermentation process in this distillery. Torriani et al. (1999) successfully used the M13 primer to identify senso stricto Saccharomyces strains and also for intraspecies differentiation. The authors were able to differentiate $S$. cerevisiae strains with different phenotypes using the primer M13. Lieckfeldt et al. (1993), using the M13 primer, showed the differences among $23 \mathrm{~S}$. cerevisiae strains associated with different fermentation products (wine, beer, spirits, as well as bakery products).

Guerra et al. (2001) were able to differentiate the $S$. cerevisiae strains from the spontaneous fermentation for cachaça production using primer M13. In that study, the authors detected a high degree of genetic polymorphism among the strains within a 24-h fermentation cycle for the production of cachaça. In the present study, this technique was also accurate when used to discriminate the isolates of the two strains used as starters during the fermentation for cachaça production.

The characterization of strains that could potentially be used as starters and the observation of such strains using molecular techniques are important for the determination of the time these strains remain in the fermentation process. The results of the present study revealed that two strains were able to prevail in the process for approximately 30 days. Therefore, with periodic yeast replacement, it should be possible to maintain a higher degree of cachaça homogeneity throughout the production season and between the seasons, thus affording a higher quality standard for the beverage.
A

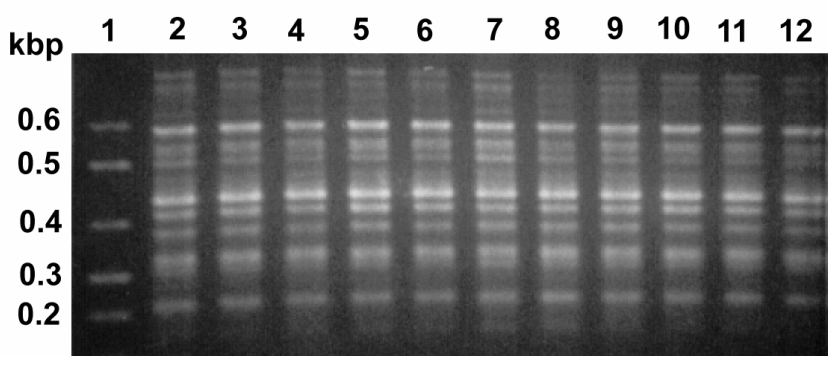

B

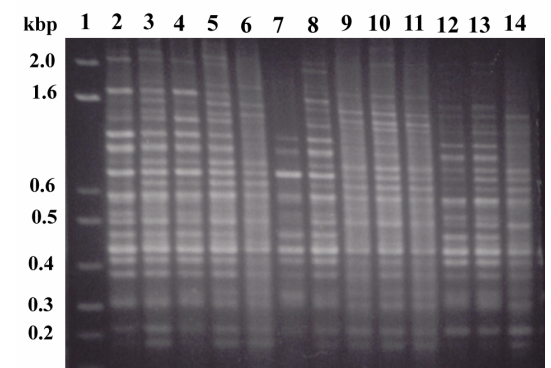

Figure 1 - RAPD-PCR comparison between the respective starter strains inoculated in fermentation vats with two isolates from the prevailing morphotype of each collection during the experiment carried out in a cachaça distillery. Fig. 1A: lanes: 1, 1 kbp ladder; 2, Saccharomyces cerevisiae K1-V116; 3 and 4, S. cerevisiae K1V116 re-isolated after 3-day fermentation; 5 and $6, S$. cerevisiae K1-V116 reisolated after 5-days; 7 and 8, S. cerevisiae K1-V116 re-isolated after 11-days; 9 and 10, S. cerevisiae K1-V116 re-isolated after 18-days; 11 and 12, S. cerevisiae K1V116 re-isolated after 28-days. Fig. 1B: lanes: 1, $1 \mathrm{kbp}$ ladder; 2, S. cerevisiae UFMG-A829; 3 and 4, S. cerevisiae UFMG-A829 re-isolated after 3-days of fermentation; 5 and 6, S. cerevisiae UFMG-A829 re-isolated after 5-days; 7 and 8, S. cerevisiae UFMG-A829 re-isolated after 11-days; 9 and 10, S. cerevisiae UFMGA829 re-isolated after 18-days; 11 and 12, S. cerevisiae UFMG-A829 re-isolated after 28-days, 13 and 14, S. cerevisiae UFMG-A829 re-isolated after 34-days. 


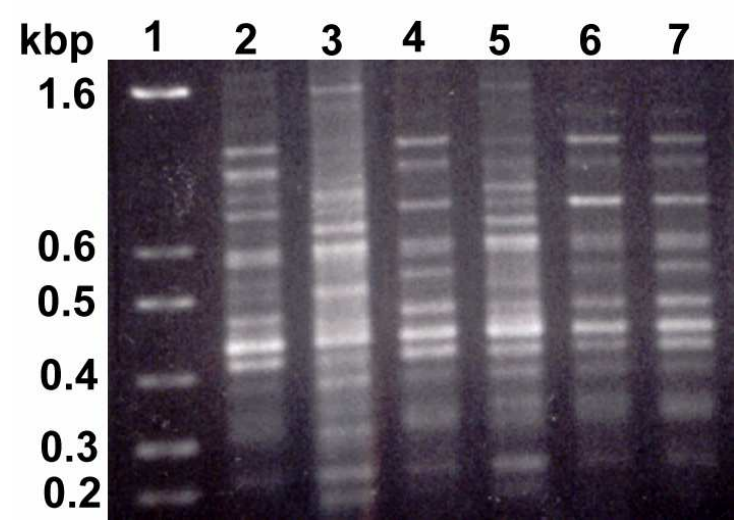

Figure 2 - RAPD-PCR comparision between starter strain UFMG-A 829 and S. cerevisiae isolates with rough colonial texture and irregular margins. Lanes: 1- $1 \mathrm{kbp}$ ladder; $2-S$. cerevisiae UFMG-A 829; 3 and 5 indigenous $S$. cerevisiae; 4, 6 and 7 identical to $S$. cerevisiae UFMG-A 829.

\section{ACKNOWLEDGEMENTS}

This work was supported by the Conselho Nacional de Desenvolvimento Científico e Tecnológico (CNPq) and Fundação de Amparo à Pesquisa do Estado de Minas Gerais (FAPEMIG).

\section{RESUMO}

Duas linhagens de Saccharomyces cerevisiae foram testadas como iniciadoras em uma destilaria de cachaça. Foram utilizadas as linhagens de $S$. cerevisiae UFMG-A829, isolada de fermentação de cachaça, e $S$. cerevisiae K1-V1116, de origem vinícola. A permanência de cada linhagem durante a fermentação foi determinada por RAPD (Random Amplified Polymorphic DNA)-PCR, utilizando o iniciador M13. As duas linhagens predominaram nas dornas de fermentação por aproximadamente 30 dias. Leveduras nãoSaccharomyces e S. cerevisiae indígenas foram isoladas em menor proporção durante o experimento. As linhagens de $S$. cerevisiae indígenas apresentaram perfis moleculares distintos em relação às linhagens iniciadoras. As duas linhagens foram promissoras para serem utilizadas como iniciadoras do processo fermentativo para a produção da cachaça.

\section{REFERENCES}

Aidoo, K. E.; Nout, M. J. R. and Sarkar P. K. (2006), Occurrence and function of yeasts in Asian indigenous fermented foods. FEMS Yeast Res., 6, 3039.

Brasil (2005) Ministério da Agricultura. Instrução normativa $n^{0} 13$ de 29 de junho de 2005. Diário Oficial da União, Brasília, 29 de junho de 2005. www.agricultura.org.br. Cited 24 Nov. 2005.

Cedeño, M. (1995), Tequila production. Crit. Rev. Biotechnol., 15, 1-11.

Dorneles, D.; Machado, I. M. P., Chociai, M. B.; Bonfim,T. M. B. (2005), Influence of the use of selected and non-selected yeasts in red wine production. Braz. Arch. Biol.Technol.,48, n ${ }^{\circ}$ 5, 747751.

Fahrasmane, L. and Parfait, G. (1998), Microbial flora of rum fermentation media. J. Appl. Microbiol., 84, 921-928.

Gomes, F. C. O.; Pataro, C.; Guerra, J. B.; Neves, M. J.; Correa, S. R.; Moreira, E. S. A. and Rosa, C. A. (2002), Physiological diversity and trehalose accumulation in Schizosaccharomyces pombe strains isolated from spontaneous fermentations during the production of the artisanal Brazilian cachaça. Can. J. Microbiol., 48, 399 - 406.

Guerra, J. B.; Araújo, R. A. C.; Pataro, C.; Franco, G. R.; Moreira, E. S. A.; Mendonça-Hagler, L. C. and Rosa, C. A. (2001), Genetic diversity of Saccharomyces cerevisiae strains during the $24 \mathrm{~h}$ fermentative cycle for production of the artisanal Brazilian cachaça. Lett. Appl. Microbiol., 33, 106111. 
Gutiérrez, A. R.; López, R.; Santamaría, M. P. and Sevilla, M. J. (1997), Ecology of inoculated and spontaneous fermentations in Rioja (Spain) musts, examined by mitocondrial DNA restriction analysis. Int. J. Food Microbiol., 36, 241-245.

Hui, Y. H.; Meunier-Goddik, L.; Hansen, A. S.; Josephsen, J.; Nip, W. K.; Stanfield, P. S. and Toldra, F. (2004), Handbook of Food and Beverage Fermentation Technology. Marcel Dekker, NewYork, NY.

Kunkee, R. E. and Bissson, L. F. (1993), Wine-making yeasts. In-The Yeasts: Yeast technology, ed. Rose, A. H., Harrison, J. S. Academic Press, London, pp. 69127.

Kurtzman, C. P. and Fell, J. W. (1998), The yeasts: A Taxonomic Study, 4 th edition. Elsevier Amsterdam.

Lieckfeldt, E., Meyer, W. and Borner, T. (1993), Rapid identification and differentiation of yeast by DNA and PCR fingerprinting. J. Basic Microbiol., 33, 413426.

Melo, D. L. F. M.; Santos, F. C.; Barbosa Jr., A. M.; Santos, P. O.; Carnelossi, M. A. G. and Trindade, R. C. (2007), Identification of yeasts isolated from the pulp in nature and the production of homemade "Umbu" wine. Braz. Arch. Biol. Technol., 50, 887892.

Morais, P. B.; Rosa, C. A.; Linardi, V. R.; Pataro, C. and Maia, A. B. R. A. (1997), Characterization and succession of yeast populations associated with spontaneous fermentation for Brazilian sugar-cane "aguardente" production. World J. Microbiol. Biotechnol., 13, 241-243.

Oliveira, E. S., Rosa, C. A., Morgano, M. A. and Serra, G. E. (2004), Fermentation characteristics as criteria for selection of cachaça yeast. World J. Microbiol Biotechnol., 20, 19-24.

Pataro, C.; Santos, A.; Correa, S. R.; Morais, P. B.; Linardi, V. R. and Rosa, C. A. (1998), Physiological characterization of yeasts isolated from artisanal fermentation in an cachaca distillery. Rev. Microbiol., 29, 69-73.

Pataro, C.; Guerra, J. B.; Petrillo-Peixoto, M. L.; Mendonça-Hagler, L. C.; Linardi, V. R. and Rosa, C. A. (2000), Yeasts communities and genetic polymorphism of Saccharomyces cerevisiae strains associated with artisanal fermentations in Brazil. $J$. Appl. Microbiol., 88, 24-31.
Pataro, C.; Guerra, J. B.; Gomes, F. C. O.; Neves, M. J.; Pimentel, P. F. and Rosa, C. A. (2002), Trehalose accumulation, invertase activity and physiological characteristics of yeast isolated from $24 \mathrm{H}$ fermentative cycles during the production of artisanal Brazilian cachaça. Braz. J. Microbiol., 33, 202-208.

Romano, P.; Caruso, M.; Capece, A.; Lipani, G.; Paraggio, M. and Fiore, C. (2003), Metabolic diversity of Saccharomyces cerevisiae strains from spontaneously fermented grape musts. World $J$. Microbiol. Biotechnol., 19, 311-315.

Torriani, S.; Zapparoli, G. and Suzzi, G. (1999), Genetic and phenotypic diversity of Saccharomyces cerevisiae sensu stricto strains isolated from Amarone wine. Antonie van Leeuwenhoek, 75, 207-215.

Valero, E.; Schuller, D.; Cambon, B.; Casal, M. and Dequin, S. (2005), Dissemination and survival of commercial wine yeast in the vineyard: a large-scale, three-years study. FEMS Microbiol. Lett., 5, 959-969.

Victoria Lopez, Fernandez-Espinar, M. T.; Barrio, E.; Ramon, D. and Querol, A. (2003), A new PCR-based method for monitoring inoculated wine fermentations. Int. J. Food Microbiol., 81, 63-71.

Wood, B. J. B. (1998), Microbiology of Fermented Foods. 2nd edn. Blackie Academic and Professional, London, UK.

Yarrow, D. (1998), Methods for the isolation, maintenance, classification and identification of yeasts. In-The Yeasts: A Taxonomic Study. Eds. Kurtzman, C.P., Fell, J. W. Elsevier, Amsterdam, pp. 77-100.
Received: October31, 2006; Revised: May 30, 2007; Accepted: June 11, 2008. 